European journal of American studies

\title{
Coming Out in Poland
}

Tomasz Basiuk

\section{(2) OpenEdition \\ Journals}

Electronic version

URL: https://journals.openedition.org/ejas/13519

DOI: 10.4000/ejas.13519

ISSN: 1991-9336

Publisher

European Association for American Studies

\section{Electronic reference}

Tomasz Basiuk, "Coming Out in Poland", European journal of American studies [Online], 13-3 | 2018,

Online since 23 January 2019, connection on 08 July 2021. URL: http://journals.openedition.org/ejas/ 13519 ; DOI: https://doi.org/10.4000/ejas.13519

This text was automatically generated on 8 July 2021 .

Creative Commons License 


\title{
Coming Out in Poland
}

\author{
Tomasz Basiuk
}

1 In a 1981 interview for Gai Pied, a magazine he helped establish, Michel Foucault referred critically to gay coming out as an American invention. His skepticism about coming out was rooted in the recognition that it mystified homosexuality as a unique type of desire, one in need of discovery and explication. Being on the receiving end of someone's coming out can easily result in the misperception that one is being let in on a secret, becoming privy to some privileged information. Encountering someone's claim that they are lesbian, gay, and so on, is likely to prompt speculation about the presumed essence of these subject positions. Foucault contended that, rather than think of it as a form of desire, we should be thinking of homosexuality as an object of desire because it bypasses the established social institutions, making alternative kinds of relation more readily visible and more compelling. Foucault's general term for these various alternatives was friendship, and his point was that homosexuality promoted friendship as a way of life. At the time, neither same-sex marriage nor registered partnership existed, so that having a same-sex partner indeed required an inventiveness that would accommodate this choice. The broad concept of friendship provided a capacious label for the emergence of homosexuality as a way of life rather than just a sexual object choice.

2 A few years prior to Foucault's interview, Jeffrey Weeks invoked the United Kingdom to argue that coming out was a social process of increasing the visibility of LGBT+ people and thereby helping them demand equal rights. In this historicizing perspective, personal coming out plays a part in the larger social process but is not equivalent to it. Visibility is achieved also by other means, such as political campaigns and media representations (Basiuk 2014). People who lead openly queer lives-those who are out in the sense of living in a same-sex relationship, for example-are constructing a queer visibility no less than those who verbally declare that they are gay or otherwise nonheteronormative. A verbal declaration of one's identity may be useful but it need not be crucial.

3 In describing homosexuality as inventing a lifestyle, Foucault is referencing this larger social process of coming out. But when he calls coming out an American invention, he 
has in mind the verbal gesture of avowing that one is gay. Just how American is such rhetorical coming out? The expression coming out is borrowed from debutantes' balls at which young upper-class women came out into society. In early queer usage, one came out into the life. Samuel R. Delany notes that in his youth coming out designated the first time one had sex with a partner of one's own gender (13). This changed in the wake of the Stonewall Inn riots of 1969 , when the political message about the need for public visibility, expressed in the slogan, "Out of the closets and into the streets," contributed to a shift in meaning and produced the now-current collocation, to come out of the closet, that is, to avow that one is homosexual (or otherwise not normative with regard to one's sexuality and/or gender identification). This more contemporary sense of coming out, the sense of a rhetorical avowal, began with groups such as the Gay Liberation Front and with subsequent developments, right up to testimonies found on Youtube and in social media, in which people come out as queer but do not usually mention an actual sexual experience; indeed, such rhetorical avowal may occur prior to any samesex activity. An autobiographical component, including the avowal of one's queerness, is also central to the It Gets Better campaign, initiated in the United States of America, which aims to educate and reassure younger people who may be despondent about being queer with the evidence of increasing acceptance of sexual difference, offered in the form of personal testimonies from grown-ups. Coming out in the sense of an avowal is a contemporary phenomenon that originated in American culture.

4 Personal testimonies which perform this avowal deploy it as their central rhetorical gesture. They also typically figure coming out as a life-changing decision not to be regretted. The verbal coming out is thus usually embedded in an account which leads up to one's decision to come out and which posits this decision as a crucial determinant of one's selfhood. Suzanna Danuta Walters notes that it is customary among American lesbians and gay men to swap their coming-out stories: "Coming out into the family of origin is often the first story gays tell each other, often the opening line in date comeons. It's our 'come here often?"' (197). This type of confessional narrative describes the process of self-recognition and, simultaneously, acknowledges one's identity as a way of ritually acceding to the group with which one identifies (Basiuk, Exposures 168-170). The coming-out narrative thus plays a double role. It links the older usage, coming out into the life, wherein one describes an experience leading to sexual self-awareness and shares that experience in order to join the ranks of those already in the life, to the more recent usage, coming out of the closet, wherein one performs an act of rhetorical avowal addressed to the non-queer world. These two usages approximate the two meanings of recognition: recognition as revelation resulting in self-knowledge, captured by the Aristotelian term anagnorisis, and recognition in the eyes of others, captured by the Hegelian term Anerkennung. On both these counts, the rhetorical coming out operates in the manner of testimony. It entails the giving of testimony in the sense of affirming a profoundly personal truth and in the parrhesiastic sense of speaking truth to power (Basiuk, Exposures 258-260).

5 The similarity to testimony is one way in which coming out is connected to the conversion narrative, which also combines an account of personal self-examination and self-recognition with the rite of gaining access to a group and assuming a new identity. In a comparative study of American, French, and British gay men's autobiographies, Paul Robinson contends that only contemporary Americans adopt the model of the coming-out story, modeled on the conversion narrative and thus based on a clear distinction between the closeted, shame-ridden existence prior to coming out and the 
happy resolution which follows. In this model, the experience of recognizing and acknowledging one's identity-the point of conversion-is the central tenet. Noting the prevalence of the coming-out model among American gay male writers, Robinson jokingly states, "Americans, one might say, are fundamentalists even in their perversity" (xix).

Robinson's remark pinpoints the similarity of the coming-out story to the Puritan conversion narrative, as discussed by Perry Miller and others. The conversion narrative, which was part and parcel of the Puritan confession of faith, also served as a mode of ingression into the religious congregation and, by the same token, into fullfledged political citizenship. The genre, epitomized in Jonathan Edwards' "Personal Narrative," is organized around a shift, sometimes dramatized as a specific event, which divides the narrator's life experience into the turbulent and dark time before the conversion and the moral peace and clarity resulting from it. It presents conversion as profoundly life-changing. The narrative model it provides has served other, nonreligious purposes. For example, the process of coming to political awareness may be narrated as secular conversion, and the gay coming-out story follows suit. Even though religious motivation appears to matter very little in most people's coming out, the connection between coming out and American religious and cultural history is a matter of persistent, if usually unacknowledged, heritage. Once this heritage is noted, even the term the homosexual closet is revealed as having a Puritan antecedent in the notion of closet piety, denoting a too-fastidious observance of the evangelical prescription (in Matthew 6,6) to observe in private, i.e., in the closet, rather than before the eyes of the world. However, it is not so much the religious content that matters for the coming-out story as the theologically determined dichotomy of the time before and the time after one's coming. This dichotomy defines the narrative structure of the coming-out story.

Delany remarks that the coming-out story's foregrounding of a specific event of coming out inevitably simplifies and generalizes the experience of coming to terms with one's sexuality. The actual process involves a longer-term trajectory and a more complicated learning curve. In a personal essay titled "Coming / Out," he mentions "put(ting) together a list of some twenty-two incidents involving sex" between the ages seven and fifteen, some of them heterosexual (7). Each instance represents a partial coming out, each one altering the horizon of his sexual self-awareness and preparing the way for the next stage. Delany insists that only by taking such personal trajectories into account can one do justice to the way that self-recognition takes place. But narrating their progress does not lend itself to being rendered in terms of a narrative in which a dramatic shift is the governing rhetorical gesture.

8 The rhetorical avowal of coming out as gay (or lesbian, etc.) merely describes one as belonging to a group, connected by this or that characteristic and sharing a common interest. But it does not do justice to one's self-identity. Rhetorical coming out is a significant strategy because it posits the common political identification of a group but it is an imperfect way of expressing one's individual identity. In speaking of identity labels in this way, Delany sees them as a convenience because they prompt an articulation simply by virtue of being available. In another essay, he illustrates Foucault's social constructionism by describing the way that people gathered in a large central hall for a party will drift into adjacent rooms so long as the doors to these rooms are open. By analogy, the availability of discursive categories makes it possible to occupy the subject positions which these categories name. Some people will come out 
as gay so long as this option appears on their mental landscape, placed there by others who have already come out, by the media portraying certain identities, and so on (Times Square Red... 189-190). (With Delany's imaginary example we have, in a manner, returned to the debutantes' ball, the source of the coming-out metaphor for contemporary gay culture.)

9 The conversion narrative, with its roots in Christian confessional discourse, is not a universal articulation of sexuality. Gay coming-out stories have hardly spread to European writing, including to Polish literature, where homosexual, transgender, and other queering tropes were employed by some Modernist authors in a veiled and indirect way, for example, with double ententes, or otherwise encoded in figurative language, as German Ritz has argued. This allusive mode began to yield ground to more direct expression only at the end of the twentieth century. The recent publication of personal correspondence and journals, new readings, and biographies of some Modernist greats, including Jarosław Iwaszkiewicz, Jerzy Andrzejewski, Miron Białoszewski, and Witold Gombrowicz opened up a discussion about their sexuality. Other authors broke through the veil shrouding queerness. In 1980, the émigré writer Marian Pankowski published Rudolf, a novel in which a Polish narrator enters into a dialogue with an elderly German homosexual man and revels in the man's account of his free-wheeling sexuality. (First published in London, Rudolf was reissued in Poland in 1984 and 2005.) The established writer Julian Stryjkowski, who has broached the topic of homosexuality in earlier work, published a personal essay titled "Milczenie" (Silence) in 1993, in which he addressed growing up as a Jew and a homosexual. The renowned literary scholar Michał Głowiński came out as a child Holocaust survivor and a Jew in a 1998 memoir, and as a gay man in a 2010 autobiography. Stryjkowski and Głowiński describe early homosexual encounters as transgressions they barely dared to undertake. A similar note of constraint and trauma resounds in Pankowski's Polish narrator, though not in the German man's account. These coming-out stories are rather different from the American model because they do not put forward the premise that coming out was a crucial turning point in the writer's life. They are more concerned with reminiscing and, for some, with regret.

10 A younger generation of writers has been more forthcoming. Izabela Filipiak came out as a lesbian in the public media in 1998. The work of the lesbian writer Ewa Schilling (the pseudonym of a writer who remains anonymous) struck a chord with many queer readers without becoming broadly known. In 2005, two young gay male authors published queer debut novels: Michał Witkowski is the author of Lubiewo (subsequently translated into English as Lovetown), and Bartosz Żurawiecki authored Trzech panów w tóżku, nie licząc kota, a novel whose title plays on Jerome K. Jerome's Three Men in a Boat (To Say Nothing of the Dog). In 2006, the late radio journalist Anna Laszuk, an out lesbian, published a collection of lesbian biographies Dziewczyny, wyjdźcie z szafy!, based on interviews with lesbians, whose title beseeches women to come out of the closet. Not all of these publications fit the coming-out mold, however. For example, Witkowski's protagonists, two elderly queens whose prime was in the days of "real socialism," eye the contemporary, politicized gay man with much suspicion. And Laszuk's call for lesbians to come out of the closet has largely remained unanswered.

11 This is not to say that coming out is altogether absent from public life. Several male actors have come out, including Marek Barbasiewicz and Jacek Poniedziałek. There is a handful of out gay male politicians (Robert Biedron and Paweł Rabiej are the most 
known), and the transgender woman Anna Grodzka served as member of the parliament in the 2011-2015 term. Promoting coming out is a major strategy used by the mainstream LGBT+ groups. For example, the bimonthly magazine Replika, published by the organization Campaign Against Homphobia (KPH), regularly interviews men and women who have come out. These interviewees are usually people with some public standing, for example, a university professor, the head of a local self-government body, or a young-and-coming actor, who are implicitly presented as role models. Replika also carries information about internationally known celebrities who have come out (many of them American), as well as articles about LGBT+ rights and the struggle for these rights in the past and in the present, including in the United States.

There is little question, however, that coming out is far less common in Poland than in the U.S. Coming out is often seen as a cultural import, a gesture for which there is no established protocol and which can easily turn into embarrassment for both those who attempt it and those being addressed. Robert Gliński's documentary Homo.pl, structured around interviews with lesbian and gay couples, does not acknowledge that almost all of the interviewees are former or current LGBT+ activists, a circumstance suggestive of how difficult it may be to find individuals willing to broadcast their sexuality to the public (Basiuk, "Coming Out and Beyond"). At the same time, the unease about being out may be declining. A growing number of university students seem to be out. At the University of Warsaw, a student group named Queer UW, founded in 2011, has sponsored conferences, film screenings, debates, and other extracurricular activities, helping promote, as well as report on, an LGBT+ friendly environment. A 2016 survey showed that $14 \%$ of the University of Warsaw self-selected student respondents did not know any peer who was out, while a third believed that coming out while at the university could have negative consequences (Drozdowski, 15-17).

13 The precarious status of coming out in Poland as a strategy promoted by the mainstream LGBT+ discourse and, simultaneously, a foreign import and thus something requiring an explanation may be illustrated with Jerzy Krzyszpien's recent inspirational self-help manual Wychodzimy z ukrycia (We're Come Out From Hiding), forthcoming in 2018. The manual makes the familiar point that a personal coming out is a matter of personal dignity, as well as a crucial political tool which affects other individuals and has the potential to help them. The book's author, an accomplished translator who has rendered into the Polish John Boswell's seminal Christianity, Social Tolerance, and Homosexuality, alongside a host of other relevant publications, is a university lecturer and an influential figure on the Polish LGBT+ scene. He has written previously on the language of LGBT+ emancipation and has successfully persuaded activists to stop calling homosexuality with the masculine noun homoseksualizm, which suggests a medical diagnosis, and to use instead the friendlier-sounding feminine noun homoseksualność. (The difference is analogous to that between the German words Homosexualismus and Homosexualität.) The recent manual includes other pragmatic recommendations about how to come out and how to talk about one's sexuality while avoiding the impression that one's words are direct borrowings (usually from the English), or that one is engaging in awkward, wooden mimicry.

14 The unspoken but quite apparent premise in Wychodzimy z ukrycia is that coming out is indeed a cultural import. This is especially visible in the wide selection of inspirational quotes which pepper the book. Most of them translations from the English, as if coming out was naturally linked to being able to converse in English. There are numerous 
mentions of American activism and U.S. government policy. The It Gets Better campaign receives considerable attention and Secretary Hillary Clinton's 2011 speech in Geneva on the anniversary of the Universal Declaration of Human Rights, in which she focused on LGBT rights, is quoted in extenso (in Polish translation). These choices are meaningful, as the United States is consistently presented as inspirational for the LGBT+ human rights struggle worldwide.

Krzyszpień's focus on the United States is motivated in part by his personal experience. In a short autobiographical chapter-his own coming-out story-Krzyszpień describes his time on a scholarship in the United States in the mid-1970s. In the course of his college year abroad, he discovered and avidly read publications on homosexuality. He confided in a pen pal and in an older woman friend, receiving support and advice. This positive experience was in a stark contrast to the situation back home. Krzyszpien returned to Poland a changed man but found that most homosexual men there were either uninterested in being out or too oppressed and too scared to come out. His attempts to write about gay rights and to publish relevant translations from the English were blocked. Homosexuality and any sexual otherness were absent from the Polish public discourse. The United States was thus the author's main point of reference in those days and has remained so ever since.

In Wychodzimy $z$ ukrycia, Krzyszpien reaffirms his long-standing position on the necessity of demanding equal rights, rather than merely tolerance, by repeatedly bringing up same-sex marriage. His argument for same-sex marriage reflects his stance on coming out. He offers little discussion of marriage as an institution, and the purpose of a brief comparison between marriage and registered partnership is to show that only marriage provides full equality. Same-sex marriage is thus presented as the logical next step in the struggle initiated with coming out. Like the call to come out, the demand for marriage equality combines a consideration of personal dignity with the larger context of political rights. While same-sex marriage has become the law of the land in some countries, including in the U.S., the demand for access to marriage is a fairly radical one in Poland, where same-sex unions remain unrecognized. Indeed, a demand for same-sex marriage has not been articulated by any political party or mainstream LGBT+ organization. On this point, Krzyszpien is on a frolic of his own as he reiterates his earlier strategy of finding a progressive standard abroad and trying to make it resonate in the Polish context.

17 A number of marginal points in Wychodzimy z ukrycia also adopt a perspective easily recognizable as stemming from the American context. For example, Krzyszpień mentions in passing that telling one's parents that one is practicing safer sex can reassure them and bolster one's chances for a successful coming out. Because there has not been a major HIV/AIDS epidemic in Poland, the absence of any reference to HIV/ AIDS (or any other STD) makes this point ambiguous, not least because it implies that young homosexuals are more promiscuous than young heterosexuals. The underlying reason is that the advice seems transplanted from the American context without clear indication that the Polish context may be different.

Krzyszpień is critical of some other borrowings. He considers the terms queer and heteronormativity but finds them unsuitable for the work of coming out because they are all but impossible to render in plain Polish. They are also difficult to explain to the uninitiated. Queer refuses to clearly denote an identity position, defying the strategy of coming out. Krzyszpień sees the term's growing popularity among the left-leaning 
young Polish queers as a threat, although in many instances the more typical LGBT+ politics go hand-in-hand with the queer alternative. For example, the magazine Replika, which regularly publishes coming-out interviews, has the acronym LGBTQ in its subtitle and the word queer pops up on its pages at least occasionally. Another popular LGBT+ website is called queer.pl. In short, the contradiction between LGBT+ and specifically queer theorizing and activism is less pronounced in Poland than it is in the United States and in the West more broadly. (Joanna Mizielińska and Robert Kulpa have written on the convoluted temporality of the Polish LGBT+ context which defies a characterization in terms of either progress or regression.) The term heteronormativity, coined by Michael Warner and often used as a cognate of homophobia, denotes a more specifically systemic understanding of the way that a binary concept of gender and the expectation of heterosexuality (called "compulsory heterosexuality" by Adrienne Rich) determine a range of norms pertaining to sexuality and to gender. Krzyszpień acknowledges this term's broadening currency in the Polish public debate but, like in the case of queer, he sees it diffusing the positive impact of coming out. In pitting the identity-based strategy of coming out against the queering strategy, he appears, once again, to be transplanting a debate embedded in a specifically American context to the Polish one, where the conflict is either absent or more subdued, and where the debate is ultimately shaped by other considerations, such as the heteronormative conglomerate of religious and national identity and the prevalence of Catholic religious instruction offered at public schools.

Edmund White's autobiographical novel A Boy's Own Story (1982) has been called the prototypical American gay coming-out story. For example, Robert McRuer makes this point even as he is critical of the novel's limitations. A Boy's Own Story was translated into the Polish by Jerzy Jarniewicz in 1998 after an excerpt (in another translation) was published in the influential monthly Literatura na świecie, which devoted an issue to White in 1997. The magazine's selection placed A Boy's Own Story in the context of work which did not focus on being gay, underscoring White's literary talent. However, a short personal testimony by Miras Soliwoda, a self-avowed gay man from Poland who had been White's house guest in Paris, was also included, intimating that White's gaythemed work was grounded in the writer's life. Reissued by another publisher in 2012 and noted by the LGBT+ community (e.g. Queer.pl), A Boy's Own Story never quite achieved cult status as a gay text in Poland even though literary representations of homosexuality offered in Polish translation have traditionally played an important role in gay men's self-definition, as is evidenced in life writing and epistolary writing from the 1970s and 1980s, and by the unofficial circulation of literary translations in mimeographed and carbon copies of typescript. Perhaps White's translation came too late to play a similar role, as Poland was already undergoing a major socio-economic transition and many kinds of cultural artefacts and texts were rapidly becoming available, crowding out a novel which might otherwise have played a culturally formative role in the way that James Baldwin's novels and some other texts have done. It may also be that White's novel did not resonate with Polish readers because a coming-out narrative, focused on the psychological turmoil and hardship associated with staying in the closet, seemed either too alien to these readers or too close for comfort, especially as most gay male readers would not have been out. In other words, either the whole coming-out paradigm was foreign to them and the novel had little bearing on how most gay men in Poland construed their identity, or else it merely reiterated the Polish gay male readers' closeted status in a way that made it less than 
interesting to them. (An additional reason may be that White's writing demands from the reader a level of familiarity with the American realities of class and race, the rituals of life at a boarding school, and so on, without making these things a point of focus and thus without harboring a fascination that might have an easy heuristic effect for the reader.)

20 A Boy's Own Story is an early example of the coming-out story but it is also more complex than the label coming-out story implies. White plays with this model without fully engaging it. The novel's first-person narrator very nearly comes out without quite achieving this end. He is out in some contexts but not in others. He grows into his sexuality but is never completely at ease with himself. He works through his issues in therapy and in other ways but fails to achieve emotional clarity. Ultimately, he undermines his own coming out with an act of betrayal tinged with internalized homophobia. The following analogy suggests itself: If verbal coming out may be described as a performative speech act because it does not merely announce one's identity but makes it real by using words, then White's novel functions more like a periperformative, to invoke Sedgwick's term for an utterance which approximates a performative speech act or occurs in its vicinity. Ultimately, White's periperformative narrative in which the resolution of a coming out is obstructed is the more realistic alternative to the prototypical coming-out story, especially as the novel's events are set prior to 1969 , before coming out as avowal became common.

21 The concept of the periperformative as an incomplete gesture, one ridden with tensions and complexities, seems to correspond to the Polish context more closely than does the performative speech act of coming out. While queerness has a far greater visibility in today's Poland than it did a decade ago, and while there is increasing social acceptance of homosexuality, its legal status has remained unchanged (except for the adoption of a rarely used non-discrimination clause in the labor code, required for membership in the EU). Homosexual acts have not been criminalized since the interwar period, and the law has remained silent on the topic, reflecting and reiterating a social taboo. Same-sex couples remain unrecognized. A bill regulating gender reassignment, sponsored by the transgender MP Grodzka and adopted by the outgoing parliament in 2015 , was promptly vetoed by the newly elected head of state. With the leftist parties out of parliament altogether and in apparent disarray, no clear political agenda for LGBT+ rights is being articulated.

Given the uneven cultural and socio-political landscape, one in which both progress and regression occur and are to be expected, the periperformative model seems more in tune with the rhythm of the developments than the affirmative stance of a performative speech act. The announcing of one's gayness (or another identity position), which is simultaneously its performative verbal production, requires a clarity about what the act entails. That is what John L. Austin meant by meeting the conditions of felicity for performative speech. In a context in which such clarity is largely absent, one cannot come out quite in the way that a manual such as Krzyszpien's Wychodzimy $z$ ukrycia presupposes. When coming out in the context of legal and discursive upheaval, one inevitably becomes entangled in positionalities and claims that attach to one's speech in ways that one may not even intend. The connection drawn by Krzyszpień between coming out and the demand for same-sex marriage illustrates this point because the agenda is his own rather than consensually adopted. However persuasive 
Krzyszpien's argument may be, the connection is tenuous and arbitrary because there is no locally available discursive context in which to embed it.

Coming out into the life is increasingly the standard in Poland, helping to build a sense of community. Coming out of the closet, on the other hand, is mostly a matter of the larger, long-winded process of increasing LGBT+ visibility, described by Weeks and postulated by Foucault. This process is likely to entail various hard-to-predict vagrancies. A straightforward articulation of one's identity as lesbian, gay, bisexual, or transgender to the outside world is likely to facilitate this process and may be strategically necessary. However, such avowal is not regarded as standard. It is also inevitably opaque given the absence of a consensually adopted and clearly articulated LGBT+ agenda.

Basiuk, Tomasz. "Coming Out and Beyond: Polish and American Representations of Sexual Minorities." Ad Americam 15 (2014): 55-65. Print.

---. Exposures. American Gay Men's Life Writing since Stonewall. Frankfurt/Main: Peter Lang, 2013. Print.

Delany, Samuel R. “Coming / Out." Boys Like Us. Gay Writers Tell Their Coming Out Stories.

Ed. Patrick Merla. New York: Avon Books, 1996. Print.

---. Times Square Red, Times Square Blue. New York and London: New York University Press, 1999. Print.

Demadre-Synoradzka, Anna. Jerzy Andrzejewski. Przyczynek do biografii prywatnej.

Warszawa: Wydawnictwo Krytyki Politycznej, 2017. Print.

Drozdowski, Mariusz [aka. Jej Perfekcyjność], ed. Wyobcowane, wyobcowani. Raport z

badań nad sytuacją osób LGBTQ studiujących na Uniwersytecie Warszawskim. Queer UW.

2016. http://queer.uw.edu.pl/wp-content/uploads/2017/02/

raport_z_badania_2016_e.pdf.

Foucault, Michel. Interviewed by Rene de Ceccaty, Jean Damet and Jean LeBitoux. "De

l'amitié comme une mode de vie." Gai Pied Best 1979-1991: 34-36. Originally published in Gai Pied 25 (April 1981). Print.

Głowiński, Michał. Czarne sezony. Warszawa: Open, 1999. Print.

---. KrĘgi obcości. Opowieść autobiograficzna. Kraków: Wydawnictwo Literackie, 2010.

Print.

Homo.pl. Documentary. Robert Gliński, dir. Filmcontract Ltd., HBO Polska, 2007.

Iwaszkiewicz, Jarosław. Wszystko jak chcesz. 0 miłości Jarosława Iwaszkiewicza do Jerzego

Błeszyńskiego. Ed. Anna Król with Malwina Mus. Warszawa: Wilk \& Król Oficyna

Wydawnicza, 2017. Print.

Krzyszpień, Jerzy. “J̨̨zyk i emancypacja LGBT: uwagi praktyczne.” Queer Studies.

PodrĘcznik kursu. Ed. Jacek Kochanowski, Marta Abramowicz, and Robert Biedroń.

Warszawa: Kampania Przeciw Homofobii, 2010. 139-146. Print.

---. Wychodzimy z ukrycia. Ujawnianie siĘ lesbijek, gejów, biseksualnych i transpłciowych+.

Kraków: Korporacja Ha!art, 2018.

Kulpa, Robert, and Joanna Mizielińska, eds. De-Centering Western Sexualities: Central and

Eastern European Perspectives. Farnham: Ashgate, 2011. Print.

Laszuk, Anna. Dziewczyny, wyjdźcie z szafy! Płock: Fundacja Lorga, 2006. Print.

McRuer, Robert. The Queer Renaissance. Contemporary American Literature and the

Reinvention of Lesbian and Gay Identities. New York and London: New York University

Press, 1997. Print.

Miller, Perry, and Thomas H. Johnson. The Puritans. Volumes 1 and 2. 1938. New York: Evanston and London: Harper Torchbooks, 1963. Print. 
Niżyńska, Joanna. The Kingdom of Insignificance: Miron Białoszewski and the Quotidian, the Queer, and the Traumatic. Evanston: Northwestern University Press, 2013. Print.

---. Traumatyczne, codzienne, queer. Królestwo wieloznaczności Mirona Białoszewskiego. Trans. Agnieszka Pokojska. Kraków: Universitas, 2018. Print.

Pankowski, Marian. Rudolf. Kraków: Ha!art, 2005 (1980). Print.

Queer.pl. "KsiĄżki o tematyce LGBT: Edmund White, Zuch" [Note on Edmund White's A Boy's Own Story reissued in 2012]. https://queer.pl/ksiazka/4339/zuch-edmund-white.

Ritz, German. Nić w labiryncie pożĄdania. Gender i płeć w literaturze polskiej od modernizmu do postmodernizmu. Trans. Bronisław DrĄg, Andrzej Kopacki and Małgorzata Łukasiewicz. Warszawa: Wiedza Powszechna, 2002. Print.

Robinson, Paul. Gay Lives. Homosexual Autobiography from John Addington Symonds to Paul Monette. Chicago and London: The University of Chicago Press, 1999. Print.

Sedgwick, Eve Kosofsky. "Around the Performative. Periperformative Vicinities in Nineteenth-Century Narrative." Touching Feeling. Affect, Pedagogy, Performativity. Durham and London: Duke University Press, 2003. 67-91. Print.

Schilling, Ewa. Lustro. Wybór opowiadań. Olsztyn: Infopress, 1998. Print.

Soliwoda, Miras. “Dzień z Amerykaninem w Paryżu." Literatura na świecie 3/1997 (308):

196-200. Print.

Stryjkowski, Julian. Milczenie. Kraków: Wydawnictwo Literackie, 1993. Print.

Suchanow, Klementyna. Gombrowicz. Ja, geniusz. Volumes 1 and 2. Wołowiec:

Wydawnictwo Czarne, 2017. Print.

Walters, Suzanna Danuta. All the Rage: The Story of Gay Visibility in America. Chicago and London: The University of Chicago Press, 2003 (2001). Print.

Warner, Michael, ed. Fear of a Queer Planet: Queer Politics and Social Theory. With an introduction by the editor. Minneapolis and London: University of Minnesota Press, 1991. Print.

Weeks, Jeffrey. Coming Out. Homosexual Politics in Britain from the Nineteenth Century to the Present. London: Quarter Books, 1977. Print.

White, Edmund. A Boy's Own Story. New York: E. P. Dutton, 1982. Print. ---. “Opowieść chłopca” [an excerpt from A Boy’s Own Story]. Trans. Krzysztof Zabłocki. Literatura na świecie 3/1997 (308): 173-195. Print.

---. Zuch [A Boy's Own Story]. Trans. Jerzy Jarniewicz. Warszawa: Państwowy Instytut Wydawniczy, 1998. Print.

---. Zuch [A Boy's Own Story]. Trans. Jerzy Jarniewicz. Wrocław: Biuro Literackie, 2012. Witkowski, Michał. Lovetown. Trans. W. Martin. London: Portobello Books, 2011. Print. ---. Lubiewo. Kraków: Ha!art, 2005. Print.

Żurawiecki, Bartosz. Trzech panów w łóżku, nie liczĄc kota. Romans pasywny. Warszawa: Sic!, 2005. Print.

\section{ABSTRACTS}

Coming out of the closet, a concept originating in American culture and consistent with the paradigm of conversion, has been embraced by many Polish LGBT+ activists. However, literary 
coming-out narratives have played a relatively minor role in Polish homoerotic writings while a prominent American gay coming-out novel has not had significant resonance after it was published in Polish translation, suggesting that neither the coming-out story nor the rhetorical act of coming out has been adopted without reservation. Moreover, a contemporary call for Polish lesbian women and gay men to come out in order to promote marriage equality seems more directly aligned with the present-day U.S. political context than with any broadly accepted local activist position on the question of same-sex marriage. Given the absence of consensus about the meaning and the goal of coming out, or even its appropriateness, verbal coming out cannot function as performative speech in the Polish context, where it is better understood as periperformative speech (Eve Kosofsky Sedgwick).

\section{INDEX}

Keywords: coming out; conversion; parrhesia; periperformative; marital equality; testimony

\section{AUTHOR}

\section{TOMASZ BASIUK}

Tomasz Basiuk teaches at the University of Warsaw American Studies Center and heads the UW Institute of the Americas and Europe. He published two monographs, Wielki Gaddis: realista postmodernistyczny [The Great Gaddis: The Postmodern Realist] (2003) and Exposures: American Gay Men's Life Writing since Stonewall (2013), co-edited several volumes in American studies and in queer studies, and authored a number of articles and book chapters. He co-founded and co-edits the online queer studies journal InterAlia (since 2006). He is principal investigator in the HERAfunded project "Cruising the 1970s: Unearthing Pre-HIV/AIDS Queer Sexual Cultures" (2016-2019). He currently serves as President of the Polish Association for American Studies. 